\title{
Power in Play: A Foucauldian Reading of A.O. Soyinka's The Trials of Brother Jero
}

\author{
Mahboobeh Davoodifar (Corresponding author) \\ English Language and Literature Department \\ Azarbaijan Shahid Madani University \\ E-mail: Mahboobeh.Davoodifar@gmail.com \\ Moussa Pourya Asl \\ School of Humanities, Universiti Sains Malaysia \\ 11800 USM, Pulau Pinang. Penang, Malaysia \\ E-mail: Ms_pourya@yahoo.com
}

Doi:10.7575/aiac.alls.v.6n.6p.63

URL: http://dx.doi.org/10.7575/aiac.alls.v.6n.6p.63
Received: 11/06/2015

Accepted: 01/09/2015

\begin{abstract}
This work utilizes Foucault's articulations on the power strategies of our contemporary society. To him the subject's constitution is never a purely passive effect of power on the subject but requires the subject's own activity. This necessitates the existence of a dynamic, mutually affecting relationship, implying that one can be both dominated and dominate at different times and in different contexts. This article aims to analyze the Nigerian Noble Laureate, Wole Soyinka's play The Trials of Brother Jero, a prophetical play that criticizes the ills of society through its satirical depiction, in the light of Foucault's conceptualizations on power. To do this, the article first clarifies Foucault's mature understanding of the operation of power and then attempts to provide an in-depth analysis of the structure of the power regime and its relations in the play, tactics of domination, and more importantly, the characters' relations to the existing system of power. The study of the language and the dialogue of the main characters, Brother Jero, Amope, Chume and a Member of Federation House not only exposes the sources of operating power relations, but it also highlights the characters' desire for power and the way it flows and slips from one character to another. The findings of the paper reveals that power is not concentrated on merely one character or institution within the play, rather, it circulates, and through the active resistance of the dominated characters, it constantly engenders new meanings within the structure of the play. In The Trials of Brother Jero, different characters have the desire to use power against each other and the resistance of each of them indicates that power is neither possessive nor repressive.
\end{abstract}

Keywords: Michel Foucault, Power, Pastoral Power, Resistance, Wole Soyinka

\section{Introduction}

The Trials of Brother Jero, widely known as one of Soyinke's (1934-?) most popular plays, was first published in 1964, and then appeared as a performance at the Greenwich Mews Theatre in New York City in 1967. The play is a popular comedy in the language (perhaps it is the only work by Soyinka that is written in simple English) of the masses. For the most part, it mocks the effects of the rapid spread and wide popularity of Christianity across Africa. The playwright touches upon the issue with a common figure of the time: i.e. a corrupt priest, a phony preacher named in the play as Prophet Jero, who proselytizes by deceiving his followers. In the play, Jero buys a velvet cape from a woman trader, Amope, on credit, for which he declines to pay and hence gives rise to numerous other conflicts of the play. Through the element of satire, the play thus successfully reveals the contradictions in blind faith and following; and highlights many of the social and political imbalances of Nigeria in the early 1960s. Perhaps, this is why, Osoba (2014) suspects, its audience tend to cut across social and intellectual classes. This being said, it is easy to note that the play engages directly with the current socio-political and religious atmosphere of the contemporary Nigeria (2).

A quick overview of Soyinka's career reveals that his works, i.e. his plays, novels, and poetry, combine elements of African cultural tradition, particularly the traditional Yoruban folk drama with European dramatic form to create sense of satire. His interest in the Yoruba culture has made him mainly focus on the problems his people are experiencing or may undergo in the postcolonial period. Thematically, his works deal with various leitmotifs and dichotomies: existentialism, the crisis of identity, nationhood and Africa's political turmoil, tradition versus modernity, and the more importantly, in terms of its relevance to the present article, the flow of the power and its relationality.

As a dramatist, poet, novelist, literary critic, theatre director, sometimes actor, Soyinka was the first Nigerian Noble Prize winner for literature in 1986. His works have hence received much public and critical reception. In an interview with Ahmed Yerima, the dramatist and social commenter, which was conducted at National Theatre of Nigeria, Lagos, the interviewer commented on The Trials of Bother Jero that the issues presented in the play were a kind of prophecy, maintaining that it "was written in 1960, at the time of writing the play, the issue of the religious proliferation was not a 
big thing then but at the moment is a big issue" (Adeoye and Jays, 222). Moreover, in a review published in African Quarterly and the Arts, The Trials of Brother Jero, Akin Adesokan has called it "perhaps the most performed of Soyinka's plays and either its comedy or its accessibility has helped it stay in various repertories, or on the reading lists (90).

Since its publication, the play has also been the target of much critical discussion. Critics have taken widely different approaches to read it from various perspectives. Some have focused on the way satire has been used to expatiate the socio-political problems of Nigerian Society (Abisola 2011; Kammampoal 2013; Sanka and Addei 2013; Beatrice \& Gyimah 2013). Others have utilized linguistic lenses, functional meaning and language (Ekpe, Oden, \& Essien-Eyo 2013; Osoba 2014). Beatrice \& Gyimah, for instance, in their paper entitled "Soyinka as Satirist: A Study of The Trials of Brother Jero" introduce Soyinka as a satirist and further explain the tools of satire such as irony, exaggeration and invective in the play. They believe that "satire is a mode of writing that exposes the failings of individuals, institutions, or societies to ridicule and scorn" (269). Meditating on satire as a social commentary and criticism, they highlight the power of language to communicate messages to the audience. Though this paper is successfully done, it is limited to the discussion of the power of the language, and thus fails to study the notion of power. Furthermore, the article excludes the power of characters and institutions that could unveil certain unique aspects of the play. In an attempt to fill out this gap, our paper investigates this play meticulously in the light of Foucauldian theory of power relations and pays particular attention to different characters in the play, their use of language, and the contribution of the language they use to the notion of the power in the play. The reason for that is power has been one of the recurrent themes in major Works of Soyinka. For instance, in The Lion and The Jewel (1959), the struggles among characters to win the village belle clearly explains the theme of power and this is approved by the fact that the Bale of the village wins her hand. Another instance can be A Dance of the Forests (1960), Soyinka's first major work, in which for the gathering of the tribes, two powerful and glorious forefathers are invited. However, the least powerful ones that have been violently abused are brought to the feast. The repetition of the notion of the power has made the researchers ponder the applicability of it to The Trials of Brother Jero. In addition to the recurrence of theme of power in Soyinka's works, the fact that The Trials of Brother Jero has been categorized as a political play makes it valuable to be analyzed with regard to Foucauldian theory of power.

\section{Theoretical Background}

Providing a genealogy of the subject in his History of Sexuality, Foucault states, "[i]t seemed appropriate to look for the forms and modalities of the relation to self by which the individual constitutes and recognizes himself qua subject" (6). Then, he begins to explore the technologies and practices that formulate the self; thereby examining the power strategies of our contemporary disciplinary society. Power is one of the recurrent themes in Foucault's works, which are largely concerned with the relations between social structures and institutions and the individual (Mills, 33). Unless one appreciates the general definition of the notion of power, one would not be able to easily comprehend it in Foucauldian terms.

In general, power is the ability of an agent that desires to impose its will over the wills of the powerless (Goudarzi and Ramin, 2014). In defining power, Foucault emphasizes that he does not intend to provide a theory of power, rather, he is involved in the ways the network of power relations operates, how power strategies structure our field of experience. This examination entails an account of power as a tool of analysis. In his first volume of The History of Sexuality, he stresses that "power is exercised from innumerable points, in the interplay of non-egalitarian and mobile relations" (94). Hence, power is not exercised on a marginalized and subordinate group by a privileged and dominant one. These roles are dynamic, suggesting that there is "no binary and all-encompassing opposition between rulers and ruled" (94). So, it is easy to conclude that one can be the subject and the object of power at the same time, one can be both dominated and dominate at different times and in various contexts. However, in both cases, both sides are actively involved, implying that when even one is dominated, this is not a purely passive relationship.

Foucault believes that the power relations are implicated in all our social relations. His definition of power departs from the Marxist articulations of the concept that consider it as a possession through which the powerful can suppress the powerless. Foucault's theory of power suggests that the system of power relations is omnipresent, that is, it can be found in all social interactions. As he asserts, “it seems to me that power is always already there', that one is never 'outside' it" (Taylor, 15). Power is not a fixed possession but a flow which circulates and is exercised and practiced. As he explains in one of his interviews published as "Critical theory/ intellectual theory", "I am not referring to power with a capital $\mathrm{P}$, dominating and imposing its rationality upon the totality of the social body. In fact, there are power relations. They are multiple; they have different forms, they can be in play in family relations, or within an institution, or an administration" (Foucault, 38).

Foucault studies power not only as a macro power in institutions, but also in smaller circles such as families and trivial conversations among family members, friends or even taxi drivers and passengers which he refers to as micro power; thus pointing to the unfixed status of power relations. In this context, Sara Mills points to the relationality and unsteadiness of the power regime and claims that Foucault's work is very critical of the notion that power is something which a group of people or an institution process and that it is only concerned with oppressing and constraining. What Foucault's work tries to do is to move from thinking about power beyond the view of power as repression of the powerless by the powerful to an examination of the way that power operated within everyday relations between people and institutions (33). In this regard, Yuan Yu (2014) concurs with Mills asserting that to Foucault, power is relations. As he observes, power is "not a thing, it is a relationship between two individuals, a relationship which is such that one 
can direct the behavior of another or determine the behavior of another" (244); therefore, individuals also play a significant role in practicing power.

In The History of Sexuality, Foucault states that "where there is power there is resistance. Should it be said that one is always "inside" power, there's no "escaping" from it (95). With regard to this statement we come to know the importance of individuals in power relations. In order to be a relation, where power is exercised there has to be someone who resists. Foucault argues that where there is no resistance, there is not, in effect, a power relation (Mills, 40). His view of power involves certain features including: 1) the impersonality, or subjectiveness, of power, meaning that it is not guided by the will of the individuals; 2) the relationality of power, meaning that power is always a case of power relations between people as opposed to a quantum possessed by people; 3 ) the decenteredness of power, meaning that it is not concentrated on a single individual or class; 4) the multidirectionary of power, meaning that it does not flow only from more to the less powerful; 5)the strategic nature of power, meaning that it has a dynamic of its own (Kelly, 38). This study aims to analyze the existing power relations in The Trials of Brother Jero. To do this, we will focus on and utilize the language and dialogue of the play and attempt to address questions like: Where is the first point in the play in which power is shown for the first time? How is power practiced and circulated by characters? Where and when do characters resist the dominating power in the play?

\section{Discussion}

The Trials of Brother Jero is a story of a day in the life of a self-named prophet, Jero. This corrupt preacher is proud of demonstrating his wise and cunning nature to the public. The play begins a monologue in which we learn about Brother Jero: The audience is told that he was born a prophet and thus, his view of prophethood as a trade is revealed at the very outset of the play. We learn that Jero acquired his current beach-side realty in the name of the Old Prophet, his former master, by formulating a campaign against the other prophets. The Old Prophet, however, is also already driven off his own land. Midway into the monologue, the Old Prophet enters to curse Jero, "wishing his downfall via women". The day is presented to us as one in which the wish is nearly fulfilled. Hereafter, a messenger in the government, called Chume and Amope, his ill-tempered wife appear. Chume is Jero's most faithful penitent. However, unbeknownst to him, Brother Jero owes Amope a sum of money for a velvet cape that he bought from her. Determined to get her money, Amope camps outside his door and after a brief confrontation Jero sneaks out to the beach. In Scene 3, we see Chume joining Jero at the beach. The scene goes on with Chume listing his grievances about his wife and requesting to beat her. Jero, however, prohibited Chume from doing so. While the rest of the congregation is gathering, Jero notices a fight between a Drummer Boy and a woman. Being distracted, he leaves to attempt to mitigate it. In the meantime, Chume temporarily takes over Prophet Jero's sermon, empowered. Returning to the congregation, Jero, very exhausted, finds out that Amope is in fact Chume's wife. There, we see him granting permission to beat her, hoping it will take care of his problems as well. In the following scene, Chume is eventually emboldened to speak with Amope, whereby he finds out that her debtor is in fact Brother Jero, and that his sacred life is built on a web of lies. Instead of beating Amope, he runs back to confront Jero. In the final scene we see Jero in the process of converting another penitent. The new member is a Member of the House who is yearning to become a Minister. Chume arrives with one determined intention in his mind: that of killing Jero. Jero, however, escapes, but, ironically, his fleeing is interpreted as a sign of his divinity by the Penitent. And when he comes back, his newest Penitent is more strongly convinced of his status as a Prophet, dedicating himself to Jero as his "Master."

Going back to the beginning lines of The Trials of Brother Jero, it starts with Jero's monologue as:

JEROBOAM: I am a prophet. A prophet by birth and inclination. You have probably seen many of us on the streets, many with their own churches, many inland, many on the coast, many leading processions, many leading processions to lead, many curing the deaf, many raising the dead. In fact, there are eggs and eggs (145).

The starting lines of the play are important to the discussion since it is the very first point in the play where the reader becomes familiar with the existing power hierarchies within the narrative. Brother Jero calls himself a prophet, a priest, a pastor. Christianity and prophethood of Jero reminds us of the Foucauldian notion of disciplinary technologies of religion. As Foucault writes:

It has often been said that Christianity brought into being a code of ethics fundamentally different from that of the ancient world. Less emphasis is usually placed on the fact that it proposed and spread new relations throughout the ancient world. Christianity is the only religion that organized itself as a church. As such, it postulates in principle that certain individuals can, by their religious quality, serve others not as princes, magistrates, prophets, fortune-tellers, benefactors, educationalists, and so on but pastors. However, this word designates a very special form of power. (333)

In this context, it is clear that this is the church and the pastoral power which gives power to Brother Jero. He calls himself a prophet and renames his duty as a trade. What he is doing, nevertheless, is not practice, preach or pray. What he does is to empower him through weakening his flock and keeping them dissatisfied: "I am glad I got here before any costumers- I mean worshippers- well, if you like customers. I always get that feeling every morning that I am a shopkeeper waiting for customers' (153). Likening the people to the customers assures the reader that people need him and they come to him since they consider him as someone who has power, the pastoral power that he has gotten from the 
church. This becomes crystal clear especially the time when we read about the day he bought the velvet cape from Amope. He says: "I don't know how she found out my house. When I bought the goods off her, she did not even ask any question. My calling was enough to guarantee the payment (152). Having this in mind, Beatrice \& Gyimah state that "the woman, Amope, was kind enough to give the white gown and velvet cape to prophet Jero on credit. Jero confessed to us that, when he 'bought the goods off her', she did not even ask any questions". This means that Amope showed him great respect and consideration as a man of God (274).

However, in the light of Foucauldian reading, it can be said that Amope was under Jero's pastoral power. In fact there are instances in the play that illuminate the ways Jero is trying to make people notice his holiness and power; the time, for instance, when he says "God curse that woman! I never thought she would dare affront the presence of a man of God" (153). There are also a few times when Jero reminds people of the presence of a man of God. To believe that Jero possesses power and is trying to suppress other characters and turn their relationship into a master-slave one is a Marxist view of power. In this regard, Althusar tells us that power is possessed by the powerful; and consequently, the less powerful are nothing but puppets that are doomed to accept the wills of the system and institutions (Goudarzi and Ramin, 2036). Rejecting this theory, Foucault asserts that power is not something to be held or possessed by governments, systems and institutions since it is not something fixed and stable. On the contrary, power in power relation is dynamic and for this reason it can be productive (ibid). In terms of the story, Jero, who is exploiting his flock as customers, is not the only person in power. The fact that Amope is sitting in front of Jero's house and he is afraid to come out and, as a result, wants to flee from the window, introduces Amope to the reader as a new source of power in the play. This incident helps the reader vote against the fixity of the power and enables them to see it like a net or relation and creates another center for the power showing the decenteredness of power hierarchies.

Chume, Amope's husband, who has been trying to get the permission to beat his wife and avoid himself from madness, can be considered an angel of the power. Chume is under the influence and power of Brother Jero and is almost begging for the permission of beating his wife. This form of power is what Foucault calls disciplinary power. For Foucault, as it is for Gramsci, power can be productive to discipline and regulate people (Gandhi and Bakhshizadeh, 2). In Foucault's words, disciplinary power strives to make the body "more obedient as it becomes more useful, and conversely" (Taylor, 28). Therefore, Chume wants to regulate Amope, and he wants to do it only once, since he sincerely believes in the disciplinary power.

Foucault insists that knowledge and power go hand in hand. In another scene, Chume confesses to Brother Jero that he has to beat his wife because in the morning she went to an area to lay siege for one week in front of her debtor's house. In their article entitled "Exploring the Foucauldian Interpretation of Power and Subject in Organization" Anita Valikangas and Hannele Seeck assert that pastoral power is a relationship, where the pastor aims to modify the spirit and the will of the guided person into a certain direction, with the help of spiritual guidance and subject's confession (9). Through Chume's confession Jero gets the knowledge. Upon knowing this, Brother Jero changes his mind.

JERO: I wonder really what the will of God would be in this matter. After all, Christ himself was not averse to using the whip when occasion demanded it.

Chume: (eagerly)... no, he did not hesitate.

JERO: in that case, since, Brother Chume, your wife seems such a wicked, willful sinner, I think ...

CHUME: Yes, Holy one ....?

JERO: You must take her home tonight ...

CHUME: Yes ...

JERO: And beat her.

CHUME: (Kneeling, Claps Jero's hand in his) Prophet!

JERO: Remember it must be done in your own house. Never show the discord within your family to the world. Take her home and beat her. (162)

Here the exploitive nature of Prophet Jero is exposed: how he cheats on others to achieve his selfish interest (Abisola, 42). In "Prison Talk", Foucault states that it is not possible for power to be exercised without knowledge. As he states "that the exercise of power perpetually creates knowledge and, conversely, knowledge can constantly induce effects of power" (52). The cooperation of knowledge and power is undeniable. With regard to the relation of knowledge and power, Foucault asserts that the set of procedures which produce knowledge and keep knowledge in circulation can be termed as 'episteme' (Mills, 71).

There are two epistemes in the play that contribute to the production and circulation of knowledge. During the confession, the pastor aims to gain more knowledge on his subjects. The result of confession is that the subject begins to produce a certain kind of truth about him- /herself (Valikangas and Seeck, 9). It is during the confession that Chume reveals the woman who has laid siege in front of Jero's house is his wife and it is with the help of this knowledge that Jero finds a way to fight against Amope's power on him. The other instance is when Chume gets the permission to beat his wife. When he arrives at Jero's house, he has been transformed. He is not the same person who obeys and listens to Amope. He thinks he has become a man and Amope should listen to whatever he says. While arguing with Amope, he acknowledges that the debtor is Prophet Jero. Chume who has been following and obeying Jero throughout the play 
wants to go back and confront him. He becomes a source of power over Jero again and when Jero hears his words from a distance, he tries to hide himself in the darkness. Jero tries to preach a member of Federation House. In the beginning the member does not care about Jero's prayers and words, saying "(with great pomposity) go and practice your fraudulence on another person of greater gullibility" (168). Jero's knowledge of the fact that the member is looking for a promotion helps him make the member believe his prophecies that he is going to be the war minister. As soon as the member hears it, he behaves with a pleading manner. Upon Jero's disappearance he says "Prophet! Prophet! (Turns sharply and rapidly in every direction, shouting) Prophet, where are you? Where have you gone? Prophet! Don't leave me, prophet, don't leave me" (170). Jero wants to use the influence of the member to send Chume to an asylum for one year and this shows that almost every character in this play has a desire for power.

What is crucial to the analysis is the resistance that characters have shown to each other's power. Jero who was the first character in power, bought a velvet cape from Amope, and in fact he had no intentions of paying for it: "God curse that woman! I never thought she would dare affront the presence of a man of God. One pound eight for this little cape! It's sheer robbery" (153). Amope, contrary to all the male characters of the play, not only does she let go of her money, but she is also brave enough to call the prophet's name, calling him bearded rogue, spindle-leg toad and dirty beggar. Even though we do not side with and appreciate Amope's insulting habit, we, likewise Mireku-Gyimah, admire her industry and desire to succeed. In a similar way, we also acknowledge her refusal to be cowed before a man and an opportunistic Christian leader at that. Here, she is an individual because she is different from many African women that are only abused first by men, and second, in the "Prophet Jero" churches (Mireku-Gyimah 270). The fact that Amope is an individual assures us that we are dealing with Foucauldian power. The notion of the individual is problematic for Foucault; nevertheless, it is in the relationship between the individual and the institution that we find power operating most clearly (Mills, 33).

\section{Conclusion}

With regard to the Foucaudian theory of power, Wole Soyinka's The Trials of Brother Jero promises a profound understanding of the play. Foucault's articulations on the power strategies of our contemporary society reveals that the subject's constitution in the society is never a purely passive effect of power on the subject but requires the subject's own activity. This necessitates the existence of a dynamic, mutually affecting relationship in the hierarchal structure of the system of power, implying that one can be both dominated and dominate at different times and in different contexts. The Nigerian Noble Laureate, Wole Soyinka's play The Trials of Brother Jero is a prophetical play that criticizes the ills of society through its satirical depictions. A study of the play in the light of Foucault's conceptualizations on power demanded us first clarify Foucault's mature understanding of the operation of power and then provide an in-depth analysis of the structure of the power regime and its relations in the play, tactics of domination, and more importantly, the characters' relations to the existing system of power. The study of the language and the dialogue of the main characters, Brother Jero, Amope, Chume and a Member of Federation House not only exposes the sources of operating power relations, but it also highlights the characters' desire for power and the way it flows and slips from one character to another. The findings of the paper revealed that power is not concentrated on merely one character or institution within the play, rather, it circulates, and through the active resistance of the dominated characters, it constantly engenders new meanings within the structure of the play. In The Trials of Brother Jero different characters have the desire to use power against each other and the resistance of each of them indicates that power is neither possessive nor repressive. The power is in play and it is not limited to the class the characters belong to, a trader, a priest, a messenger and a member of Federation House. At specific times they control each other and as the power circulates, a different character gets a significant role in the play. The main question which is still worth pondering address the socio-political aspects of the power strategies of the play.

\section{References}

Abisola, O.O. (2011). Satire and Social Meditation in Wole Soyinka's: A Case Study of The Trials of Brother Jero and A Play of Giants. Diss. University of Ilorin.

Beatrice, Patricia and Mireku-Gyimah. (2013). Soyinka as a Satirist: A Study of The Trials of Brother Jero. International Journal of English and Literature, 4(6).

Review.

.Contemporary English Language Theatre in Nigeria. African Quarterly on the Arts. Vol. I. No. 4, Londen

Ekpe, S.I., Anita, N.O., and Ako, O.E. (2013). Soyinka's Language Engineering in the Jero Plays and The Beautification of Area Boy. Studies in Literature and Language, 6.3.

Foucault, M. (1978). The History of Sexuality. Vol. I. Trans. Robert Hurley. New York: Pantheon.

(1990). History of Sexuality, Vol. 2: The Use of Pleasure, trans. R. Hurley (New York: Vintage Books, Random House, p.6.

(1980). Power/knowledge: Selected interviews and other writings 1972-1977. Ed. Colin Gordon. Trans. Colin Gordon, Leo Marshal, John Mepham, Kate Soper. New York: The Harvester Press. 
Goudarzi, A., and Zohre, R. (2014). Foucauldian Power and Identity in John Steinbeck's The Grapes of Wrath. International Research Journal of Applied and Basic Sciences 8(11).

Kammampoal, B. (2013). The Transformative Vision of Modern Society in Wole Soyinka's The Trials of Brother Jero. International Journal of Education and Research, 1(10).

Kelly, M.G.E. (2009). The Political philosophy of Michel Foucault. Londen: Routledge.

Mills, S. (2003). Michel Foucault. Londen: Routledge.

Osoba, J. (2014). A Linguistic Analysis of Wole Soyinka's The Tials of Brother Jero. Crossroads. A Journal of English Studies, 4(1).

Sanka, C.G., and Cecilia, A. (2013). Comedy As A Way Of Correcting the Ills of Society A Critical Reading of Wole Soyinkas The Trials of Brother Jero and Harold Pinters Caretaker. International Journal of Scientific and Technology Research, 2(9).

Taylor, D. (2003). Michel Foucault Key Concepts. Londen: Routledge.

Valikangas, A. and Hannele, S. (2011). Exploring The Foucaldian Interpretation of power and subject in Organizations. Journal of management and organization, 17(6).

Yu, Y. (2014). A Study of Power Relations in Pinter's Plays from Foucault's view. International Journal of Humanities and Social Science, 4(7). 